\title{
Milk Yield, Reproduction and Milk Quality Characteristics of Simmental and Red-Holstein Cattle Raised in a Dairy Farm in Aydın Province: 1. Reproduction and Milk Yield
}

\author{
Atakan Koç ${ }^{1, a, *}$, Çă̆rı Arı ${ }^{2, b}$ \\ ${ }^{1}$ Department of Animal Science, Faculty of Agriculture, Aydın Adnan Menderes University, 09100 Aydın, Turkey \\ ${ }^{2}$ Alltech Biotechnology Gıda Tar. Hay. San. ve Dış Tic. Ltd. Şti. 35030 Bornova/İzmir, Turkey \\ *Corresponding author
}

\begin{tabular}{|c|c|}
\hline A R T I C L E I N F O & A B S T R A C T \\
\hline $\begin{array}{l}\text { Received : 15/04/2020 } \\
\text { Accepted : 25/09/2020 }\end{array}$ & $\begin{array}{l}\text { In this study, fertility and milk yield characteristics of Simmental (SIM) and Red-Holstein (RH) cattle } \\
\text { raised in a private dairy farm in Aydin province were determined. For fertility traits, days open (DO), } \\
\text { calving interval (CI), gestation length (GL) and number of inseminations per pregnancy (NIPP), for } \\
\text { milk yield traits lactation length (LL), lactation milk yield (LMY), 305-days milk yield (305-dMY), } \\
\text { peak time (PT) and peak milk yield (PMY) were determined. The means of DO, CI, GL and NIPP of } \\
\mathrm{RH} \text { and SIM breeds were } 109.44 \pm 5.66 \mathrm{~d} \text { and } 96.06 \pm 3.51 \mathrm{~d}, 389.16 \pm 5.70 \mathrm{~d} \text { and } 380.37 \pm 3.54 \mathrm{~d} \text {, } \\
279.71 \pm 0.469 \mathrm{~d} \text { and } 284.94 \pm 0.303 \mathrm{~d}, 1.88 \pm 0.099 \text { and } 1.85 \pm 0.065 \text {; the means of LL, LMY, 305-dMY, } \\
\mathrm{PT} \text { and PMY were } 333.00 \pm 5.405 \mathrm{~d} \text { and } 322.72 \pm 3.233 \mathrm{~d}, 8235.32 \pm 148.099 \mathrm{~kg} \text { and } 7357.03 \pm 88.122 \\
\mathrm{~kg}, 7628.78 \pm 109.148 \mathrm{~kg} \text { and } 6938.09 \pm 64.945 \mathrm{~kg}, 46.55 \pm 2.196 \mathrm{~d} \text { and } 44.46 \pm 1.218 \mathrm{~d} \text {, and } 34.68 \pm 0.567 \\
\mathrm{~kg} \text { and } 31.47 \pm 0.314 \mathrm{~kg} \text {, respectively. Although, significant fertility and milk yield differences were } \\
\text { obtained between the breeds, the favorable performances of both SIM and RH breeds in terms of all } \\
\text { features, considered as the environmental factors such as management-feeding-housing-herd } \\
\text { management provided to animals in the farm were also suitable. }\end{array}$ \\
\hline
\end{tabular}

Non-genetic factor

Peak time

Türk Tarım - Gıda Bilim ve Teknoloji Dergisi, 8(10): 2068-2073, 2020

\section{Aydın İlinde Bir Süt Sığırı İşletmesinde Yetiştirilen Simmental ve Kırmızı-Alaca Sığırların Süt ve Döl Verimi ile Süt Kalite Özellikleri: 1. Süt ve Döl Verimi}

\begin{tabular}{|c|c|}
\hline M A K A L E B İ L G İ S İ & Ö Z \\
\hline $\begin{array}{l}\text { Anahtar Kelimeler: } \\
\text { Sığır } \\
\text { Süt verimi } \\
\text { Döl verimi } \\
\text { Çevre faktörü } \\
\text { Pik zamanı }\end{array}$ & 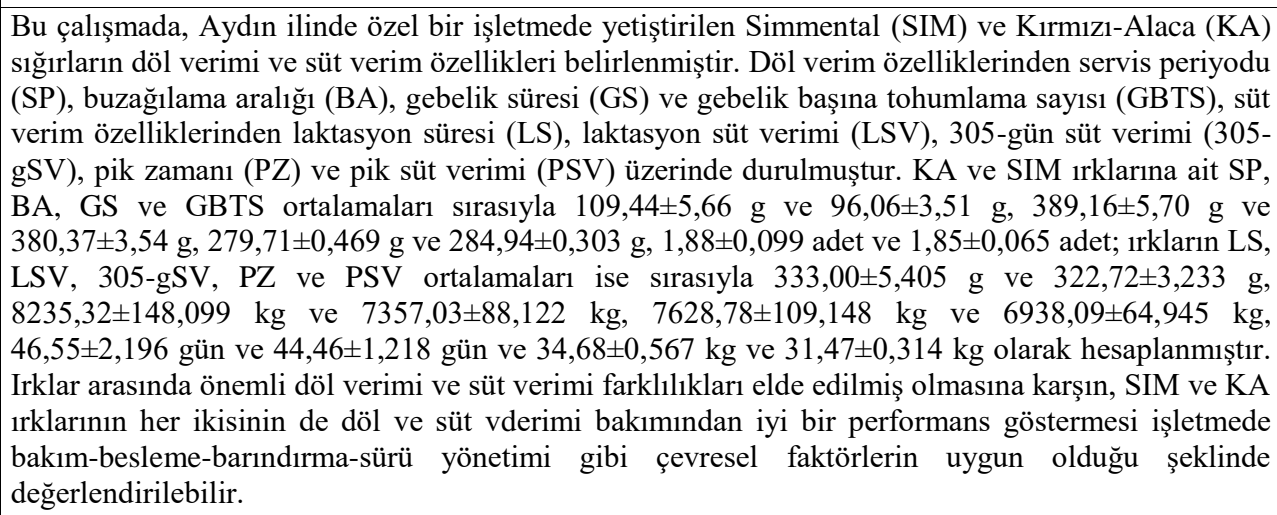 \\
\hline
\end{tabular}




\section{Introduction}

In recent years, the increasing problems in fertility, metabolic diseases, mastitis and lameness in HolsteinFriesian (HF), which is the most reared breed in the world and in Turkey, have directed the breeders to alternative breeds. In this sense, one of the prominent breeds is Simmental (SIM) and the other one is Red-Holstein (RH). The milk yield of SIM breed originating from Austria and Germany has been increased to a high level in recent years. The advantages of this breed, which has a dual-purpose origin, higher beef production potential, higher fertility and disease resistance compared to the $\mathrm{HF}$ breed, are considered as features that emphasize this breed.

SIM breed is the most preferred breed in crossbreeding in the world and in this sense, it can be said that the gene pool of this breed is constantly expanding worldwide. In fact, it is known that the different types of SIM such as Black SIM and Red SIM, which have a quite different body color than the classic SIM appearance, have been developed in the USA (Koç, 2016a). The growing interest of the breeders in Turkey to Austria and Germany SIM in recent years put this breed the second most reared breed in Turkey after HF.

Another breed that the producers have preferred more and more in recent years is RH. This breed is known as homozygous $\mathrm{HF}$ in terms of color gene ( $\mathrm{rr}$ ) and has been accepted as a different breed in many countries since it did not meet the color gene criteria in the 1950-60's.

Fertility traits were reported in various studies for SIM breed (Akbulut, 1998; Şekerden et al., 1999; Çilek and Tekin, 2005; Özkan and Güneş, 2011a; Erdem et al., 2015; Koç, 2016b) and for RH (Koç et al., 2011; Koç, 2012; 2017a). For milk yield characteristics, some results were reported for SIM breed by Akbulut (1998), Şekerden et al. (1999), Çilek and Tekin (2006), Özkan and Güneş (2011b), Erdem et al. (2015), Koç (2016b), and for RH breed Y1lmaz (2010), Koç (2015) and Koç (2017b) who reported some results for the milk yield characteristics.

In this study, the effects of various environmental factors on the fertility and milk yield characteristics of the Austrian-origin SIM and the Dutch-origin RH breeds, preferred as alternative to HF in recent years, reared in a private farm in Aydın Province, Turkey, were investigated. Since the animals were raised in the same farm, it was possible to make comparisons between the breeds in terms of fertility and milk yield characteristics.

\section{Materials and Methods}

The animal material of the study consisted of SIM and $\mathrm{RH}$ breeds raised in a dairy cattle establishment located in Sinırteke District of Incirliova County, Aydın, and the records belonging to these animals were taken from the herd management program from 2012 to 2019 used in this farm. Among the fertility traits, days open (DO), calving interval (CI), gestation length (GL) and the number of inseminations per pregnancy (NIPP); for milk yield traits lactation length (LL), lactation milk yield (LMY), 305-day milk yield (305-dMY), peak time (PT) and peak milk yield (PMY) were chosen.

\section{Statistical Analysis}

For the statistical analysis of the data, SAS (1999) package program was used, and the differences between the subgroups were determined according to the results of Tukey $(\mathrm{P}<0.05)$ multiple comparison test. The following statistical model was used in the analysis of fertility traits DO, CI, GL and NIPP and milk yield characteristics LL, LMY, 305-dMY, PT and PMY:

$$
\mathrm{y}_{\mathrm{ijklm}}=\mu+\mathrm{a}_{\mathrm{i}}+\mathrm{b}_{\mathrm{j}}+\mathrm{c}_{\mathrm{k}}+\mathrm{d}_{\mathrm{l}}+\mathrm{e}_{\mathrm{ijklm}}
$$

$$
\begin{aligned}
& \text { Where; } \\
& \mathrm{y}_{\mathrm{ijklm}} \text { : Observation of the trait } \\
& \mu \quad \text { : Mean of the trait } \\
& \mathrm{a}_{\mathrm{i}} \quad \text { : Effects of breed (i=RH and SIM) } \\
& b_{j} \text { : Effects of season ( } j=\text { winter (from November to } \\
& \text { April), summer (May to October) } \\
& c_{k} \quad \text { : Effects of calving year }(k=2012,2013, \ldots, 2018) \text {, } \\
& \mathrm{d}_{1} \quad \text { : effects of parity }(1=1,2,3,4,5,6+) \\
& \mathrm{e}_{\mathrm{ijklm}} \text { : Random error. In the analysis of NIPP, instead of } \\
& \text { calving season, insemination season and instead of } \\
& \text { calving year insemination year were used. }
\end{aligned}
$$

\section{Results and Discussion}

\section{Fertility Traits}

Averages and standard errors of DO, CI, GL and NIPP traits are given in Table 1. General averages of DO, CI, GL and NIPP were calculated as $101.79 \pm 2.26 \mathrm{~d}, 386.55 \pm 2.26 \mathrm{~d}$, $283.41 \pm 0.21 \mathrm{~d}$ and $1.93 \pm 0.044$ pieces, respectively.

The effects of breed $(\mathrm{P}<0.01)$ and calving year $(\mathrm{P}<0.05)$ on DO were determined to be statistically significant, however, calving season and parity effects were not significant $(\mathrm{P}>0.05)$. The means of DO for SIM and RH breeds were $96.06 \pm 3.51 \mathrm{~d}$ and $109.44 \pm 5.66 \mathrm{~d}$, respectively. $\mathrm{RH}$ had $13.38 \mathrm{~d}$ longer DO than that of SIM breed $(\mathrm{P}<0.01)$.

In terms of calving year, there was a gradual decrease in DO average from 2012 to 2017 and DO average, which was $117.08 \pm 8.46 \mathrm{~d}$ in 2012 , decreased to $69.94 \pm 12.31 \mathrm{~d}$ in 2017, 47.14 d difference between these two years is statistically significant $(\mathrm{P}<0.05) .2017$ is also different from 2013 and $2015(\mathrm{P}<0.05)$.

In this study, while the mean of DO found for the SIM breed $(96.06 \pm 3.51 \mathrm{~d})$ was shorter than the average as reported by Akbulut (1998) for the same breed, Şekerden et al. (1999), Çilek and Tekin (2005), and Özkan and Güneş (2011a) reported longer DO than the mean found in this study for the same breed, and quite close to the average DO value $(96.08 \pm 2.74 \mathrm{~d})$ reported by Koç $(2016 \mathrm{~b})$ for the SIM breed. On the other hand, in this study, the average of DO calculated for the $\mathrm{RH}$ breed $(109.44 \pm 5.66 \mathrm{~d})$ was not possible to compare for the DO value of the same breed since there was no previous study about this breed in Turkey.

A situation similar to the DO trait was also observed in the CI trait. The effects of breed $(\mathrm{P}<0.01)$ and calving year $(\mathrm{P}<0.05)$ on $\mathrm{CI}$ were significant, however, calving season and parity effects were insignificant $(\mathrm{P}>0.05)$. $\mathrm{RH}$ breed had $8.79 \mathrm{~d}$ longer CI average than the SIM breed and the averages of the breeds were $389.16 \pm 5.70 \mathrm{~d}$ and $380.37 \pm 3.54 \mathrm{~d}$, respectively. According to calving years, CI average from $2012(398.41 \pm 8.53$ d) to 2017 $(350.44 \pm 12.40 \mathrm{~d})$ the decrease was $47.97 \mathrm{~d}$. 
The average of CI $(380.37 \pm 3.54 \mathrm{~d})$ obtained in this study for the SIM breed was shorter from the averages reported by Akbulut (1998), Çilek and Tekin (2005) and Koç (2016b) who also reviewed the studies on the SIM breed, but the mean is longer than the average reported for the same breed by Özkan and Güneş (2011a) and Erdem et al. (2015). Also, the mean of CI found in this study for the SIM breed is shorter than the average reported for Montbeliarde (MB) and HF breeds in the review of Koç (2016b). The CI average for the RH breed (389.16 $\pm 5.70 \mathrm{~d})$ calculated in this study was shorter than the averages reported by Koç $(2011 ; 2013)$ for the same breed and the average for the CI reported by Koç (2016b) for MB and HF.

In this study, it can be said that in general, lower values were obtained for the average of DO and CI than the previous studies for both SIM and RH breeds. Achieving these low DO and CI values can be attributed to the result from the implementation of an effective management program in the enterprise. Because of the heats of cows synchronized in the enterprise in two or three groups per year, the pregnancy rate is increased and as a result, DO and $\mathrm{CI}$ are reduced.

Table 1. Means and standard errors of fertility traits

\begin{tabular}{|c|c|c|c|c|c|c|c|}
\hline Factors & $\mathrm{n}$ & DO (day) $\bar{X} \pm S_{\bar{x}}$ & CI (day) $\overline{\mathrm{X}} \pm \mathrm{S}_{\overline{\mathrm{x}}}$ & $\mathrm{n}$ & GL (day) $\overline{\mathrm{X}} \pm \mathrm{S}_{\overline{\mathrm{x}}}$ & $\mathrm{n}$ & NIPP (piece) ${ }^{\#} \bar{X} \pm S_{\overline{\mathrm{x}}}$ \\
\hline Breed & & $* *$ & $*$ & & $* *$ & & NS \\
\hline RH & 130 & $109.44 \pm 5.66^{\text {Аа }}$ & $389.16 \pm 5.70^{\mathrm{a}}$ & 191 & $279.71 \pm 0.469^{\mathrm{Aa}}$ & 182 & $1.88 \pm 0.099$ \\
\hline SIM & 438 & $96.06 \pm 3.51^{\mathrm{Bb}}$ & $380.37 \pm 3.54^{\mathrm{b}}$ & 613 & $284.94 \pm 0.303^{\mathrm{Bb}}$ & 577 & $1.85 \pm 0.065$ \\
\hline Calving Season & & NS & NS & & $*$ & & NS \\
\hline Winter & 142 & $103.00 \pm 5.43$ & $385.18 \pm 5.48$ & 261 & $282.85 \pm 0.447^{\mathrm{a}}$ & 541 & $1.90 \pm 0.073$ \\
\hline Summer & 426 & $102.50 \pm 4.07$ & $384.66 \pm 4.10$ & 543 & $281.80 \pm 0.334^{\mathrm{b}}$ & 212 & $1.83 \pm 0.091$ \\
\hline Calving Year & & $*$ & $*$ & & $* *$ & & $* *$ \\
\hline 2012 & 79 & $117.08 \pm 8.46^{\mathrm{ab}}$ & $398.41 \pm 8.53^{b}$ & 54 & $284.48 \pm 0.899^{\mathrm{Aa}}$ & 56 & $1.25 \pm 0.187^{\mathrm{Aa}}$ \\
\hline 2013 & 70 & $115.67 \pm 8.97^{\mathrm{a}}$ & $395.30 \pm 9.04^{\mathrm{a}}$ & 77 & $282.42 \pm 0.827^{\mathrm{ABab}}$ & 101 & $1.92 \pm 0.136^{\mathrm{ABa}}$ \\
\hline 2014 & 108 & $107.52 \pm 6.72^{\mathrm{a}}$ & $390.08 \pm 6.77^{\mathrm{a}}$ & 108 & $282.34 \pm 0.660^{\mathrm{ABab}}$ & 120 & $1.96 \pm 0.122^{\mathrm{Bb}}$ \\
\hline 2015 & 145 & $112.48 \pm 5.54^{\mathrm{a}}$ & $394.29 \pm 5.58^{\mathrm{a}}$ & 140 & $281.63 \pm 0.557^{\mathrm{ABab}}$ & 160 & $2.01 \pm 0.105^{\mathrm{Bb}}$ \\
\hline 2016 & 145 & $93.82 \pm 4.83^{\mathrm{ab}}$ & $381.00 \pm 4.86^{\mathrm{ab}}$ & 184 & $283.10 \pm 0.469^{\mathrm{Aa}}$ & 201 & $2.00 \pm 0.093^{\mathrm{Bb}}$ \\
\hline 2017 & 21 & $69.94 \pm 12.31^{b}$ & $350.44 \pm 12.40^{\mathrm{b}}$ & 304 & $283.11 \pm 0.414^{\mathrm{Aa}}$ & 121 & $2.03 \pm 0.123^{\mathrm{Bb}}$ \\
\hline 2018 & - & - & - & 37 & $279.20 \pm 0.946^{\mathrm{Bb}}$ & - & - \\
\hline Parity & & NS & NS & & NS & & $* *$ \\
\hline 1 & 196 & $102.05 \pm 4.96$ & $384.73 \pm 5.00$ & 232 & $281.36 \pm 0.427$ & 177 & $1.31 \pm 0.102^{\mathrm{Aa}}$ \\
\hline 2 & 141 & $99.21 \pm 6.28$ & $383.64 \pm 6.32$ & 195 & $281.91 \pm 0.486$ & 199 & $2.09 \pm 0.093^{\mathrm{Bb}}$ \\
\hline 3 & 120 & $106.89 \pm 6.15$ & $388.55 \pm 6.20$ & 148 & $281.19 \pm 0.540$ & 148 & $2.09 \pm 0.109^{\mathrm{Bb}}$ \\
\hline 4 & 72 & $94.89 \pm 8.04$ & $377.59 \pm 8.09$ & 121 & $283.18 \pm 0.600$ & 123 & $1.95 \pm 0.120^{\mathrm{Bb}}$ \\
\hline 5 & 39 & $110.71 \pm 9.85$ & $390.08 \pm 9.92$ & 71 & $282.65 \pm 0.773$ & 73 & $1.95 \pm 0.160^{\mathrm{Bb}}$ \\
\hline 6 & - & - & - & 37 & $283.66 \pm 0.976$ & 39 & $1.78 \pm 0.205^{\mathrm{ABab}}$ \\
\hline Overall & 568 & $101.79 \pm 2.26$ & $386.55 \pm 2.26$ & 804 & $283.41 \pm 0.21$ & 759 & $1.93 \pm 0.044$ \\
\hline
\end{tabular}

RH: Red Holstein, SIM: Simmental, DO: Days open, GL: gestation length, CI: Calving interval, NIPP: number of insemination per pregnancy, NS: Not significant, *: significant for $\mathrm{P}<0.05$, **: significant for $\mathrm{P}<0.01$, a,b: The difference between the groups with the same letter is insignificant for $\mathrm{P}<0.05$, A,B: The difference between the groups with the same letter is insignificant for $\mathrm{P}<0.01$. \#: In the analysis model of NIPP, insemination year and insemination season were used

The effects of breed $(\mathrm{P}<0.01)$, calving season $(\mathrm{P}<0.05)$ and calving year $(\mathrm{P}<0.01)$ on GL were determined to be statistically significant, but parity effect was not significant $(\mathrm{P}>0.05)$. The averages of GL were calculated as $279.71 \pm 0.469 \mathrm{~d}$ and $284.94 \pm 0.303 \mathrm{~d}$, respectively for $\mathrm{RH}$ and SIM breeds. The GL average of the SIM breed is 5.23 $\mathrm{d}$ longer than that of RH breed $(\mathrm{P}<0.01)$.

The average GL calculated for the SIM breed $(284.94 \pm 0.303 \mathrm{~d})$ in this study is shorter than the averages reported by Akbulut (1998) and Koç (2016b) for the same breed. However, the average of GL calculated in this study for RH $(279.71 \pm 0.469 \mathrm{~d})$ is longer than the average reported for the same breed by Koç et al. (2011). In general, GL average of the dual-purpose breeds is known to be longer than that of the dairy breeds. In this study, such result was confirmed.

According to calving years, the longest GL average was obtained in 2012 with $284.48 \pm 0.899 \mathrm{~d}$, and the shortest GL was obtained in cows that gave birth in 2018 with $279.20 \pm 0.946 \mathrm{~d}$. In terms of GL average, year 2018 is different from the years 2012, 2016 and 2017 ( $\mathrm{P}<0.01)$. In the study, it was determined that animals calving in summer gave birth for $1.05 \mathrm{~d}$ earlier than the animals calving in winter $(\mathrm{P}<0.05)$.

Insemination year and parity effects on NIPP were found to be statistically significant $(\mathrm{P}<0.01)$, however, breed and calving season effects were not significant ( $P>0.05)$. NIPP average increased according to years, and increased from $1.25 \pm 0.187$ in 2012 to $2.03 \pm 0.123$ in 2017 . The years 2012 and 2013 were found to be different from the years 2014-2017 $(\mathrm{P}<0.05)$. NIPP average for the first pregnancy $(1.31 \pm 0.102$ piece) was lower than that of the parities of $2-5(\mathrm{P}<0.01)$. This is an expected result, because estrus behaviors of the heifers are more obvious and the conception rate per insemination in heifers is higher than the rate of the cows.

It can be said that NIPP was generally lower compared to the values in RH breed in recent years. The fact that NIPP was below 2.0 could be attributed to the synchronization of the estrus from time to time and thus the 
insemination at the appropriate time in the farm. In addition, when the data were examined, it was determined that the number of inseminations belonging to a few cows was as high. It can be said that such animals were kept in operation, albeit in small numbers, and as a result of this, NIPP was increased in this herd.

In this study, the average NIPP calculated for the SIM breed $(1.85 \pm 0.065)$ was higher than the average reported by Çilek and Tekin (2005) for the same breed, Özkan and Güneş (2011a) and Erdem et al. (2015) also reported lower averages, and a similar average was reported by Koç (2016b). NIPP average ( $1.88 \pm 0.099$ pieces) calculated in this study for RH could not be compared since there was no previous study for the same breed in our country.

Table 2. Means and standard errors of milk yield traits

\begin{tabular}{|c|c|c|c|c|c|c|c|c|}
\hline Factor & $\mathrm{n}$ & $\begin{array}{c}\text { LL (day) } \\
\overline{\mathrm{X}} \pm \mathrm{S}_{\overline{\mathrm{x}}}\end{array}$ & $\mathrm{N}$ & $\begin{array}{c}\mathrm{LMY}(\mathrm{kg}) \\
\quad \overline{\mathrm{X}} \pm \mathrm{S}_{\overline{\mathrm{x}}}\end{array}$ & $\begin{array}{c}\text { 305-dMY (kg) } \\
\overline{\mathrm{X}} \pm \mathrm{S}_{\overline{\mathrm{x}}}\end{array}$ & $\mathrm{n}$ & $\begin{array}{c}\text { PT (day) } \\
\bar{X} \pm S_{\bar{x}}\end{array}$ & $\begin{array}{l}\mathrm{PMY}(\mathrm{kg}) \\
\overline{\mathrm{X}} \pm \mathrm{S}_{\overline{\mathrm{x}}}\end{array}$ \\
\hline Breed & & $*$ & & $* *$ & $* *$ & & NS & $* *$ \\
\hline RH & 130 & $333.00 \pm 5.405^{\mathrm{a}}$ & 129 & $8235.32 \pm 148.099^{\mathrm{Aa}}$ & $7628.78 \pm 109.148^{\mathrm{Aa}}$ & 78 & $46.55 \pm 2.196$ & $34.68 \pm 0.567^{\mathrm{Aa}}$ \\
\hline SIM & 426 & $322.72 \pm 3.233^{\mathrm{b}}$ & 426 & $7357.03 \pm 88.122^{\mathrm{Bb}}$ & $6938.09 \pm 64.945^{\mathrm{Bb}}$ & 271 & $44.46 \pm 1.218$ & $31.47 \pm 0.314^{\mathrm{Bb}}$ \\
\hline Calv.Season & & NS & & NS & $*$ & & NS & $* *$ \\
\hline Winter & 146 & $327.61 \pm 5$ & 146 & $7922.72 \pm 143.08$ & $7417.56 \pm 105.451^{\mathrm{a}}$ & 92 & $45.16 \pm 2.096$ & $34.02 \pm 0.541^{\mathrm{Aa}}$ \\
\hline Summer & 410 & $328.09 \pm 3.569$ & 409 & $7669.63 \pm 98.351$ & $7149.30 \pm 72.484^{\mathrm{b}}$ & 257 & $45.85 \pm 1.416$ & $32.13 \pm 0.365^{\mathrm{Bb}}$ \\
\hline Calv. Year & & NS & & $*$ & $*$ & & NS & $*$ \\
\hline 2012 & 75 & $331.55 \pm 8.299$ & 75 & $7525.75 \pm 226.11^{\mathrm{ab}}$ & $6948.71 \pm 166.64^{\mathrm{a}}$ & 34 & $43.65 \pm 3.642$ & $32.38 \pm 0.939^{a b}$ \\
\hline 2013 & 63 & $343.40 \pm 8$ & 63 & $8312.15 \pm 244.40^{\mathrm{a}}$ & $7642.60 \pm 18$ & 35 & $45.05 \pm 3.498$ & $34.60 \pm 0.902^{\mathrm{a}}$ \\
\hline 2014 & 98 & $331.98 \pm 6.680$ & 98 & $8020.12 \pm 182.00^{\mathrm{ab}}$ & $7488.23 \pm 1$ & 52 & $46.99 \pm 2.730$ & $33.53 \pm 0.704^{a b}$ \\
\hline 2015 & 136 & $331.96 \pm 5$ & 136 & $7550.82 \pm 145.16^{b}$ & $7023.57 \pm 1$ & 86 & $41.91 \pm 2$. & $31.95 \pm 0.557^{b}$ \\
\hline 201 & 145 & $318.94 \pm$ & 145 & $7678.23 \pm 126.27^{\mathrm{ab}}$ & $7297.05 \pm$ & 120 & $45.54 \pm 1$ & $32.76 \pm 0.412^{\mathrm{ab}}$ \\
\hline 2017 & 39 & $309.30 \pm 8.730$ & 38 & $7689.98 \pm 242.39^{a b}$ & $7301.43 \pm 178.64^{\mathrm{ab}}$ & 22 & $49.89 \pm 3.520$ & $33.22 \pm 0.908^{a b}$ \\
\hline Parity & & NS & & $* *$ & $* *$ & & $* *$ & $* *$ \\
\hline 1 & 195 & $330.59 \pm 4.702$ & 195 & $6711.66 \pm 128.06^{\mathrm{Aa}}$ & $6194.38 \pm 94.38^{\mathrm{Aa}}$ & 92 & $51.28 \pm 2.000^{\mathrm{Aa}}$ & $25.67 \pm 0.516^{\mathrm{Aa}}$ \\
\hline 2 & 133 & $325.17 \pm 6.020$ & 133 & $7624.42 \pm 164.23^{\mathrm{Bb}}$ & $7147.17 \pm 121.04^{\mathrm{Bb}}$ & 99 & $44.73 \pm 2.138 \mathrm{ABab}$ & $31.83 \pm 0.552^{\mathrm{Bb}}$ \\
\hline 3 & 113 & $326.58 \pm 6.144$ & 113 & $8016.93 \pm 167.44^{\mathrm{Bbc}}$ & $7541.73 \pm 123.40^{\mathrm{BCbc}}$ & 77 & $42.09 \pm 2.405^{\mathrm{Bb}}$ & $35.21 \pm 0.620^{\mathrm{Cc}}$ \\
\hline 4 & 71 & $316.33 \pm 7.399$ & 70 & $8126.99 \pm 204.02^{\mathrm{Bbc}}$ & $7781.17 \pm 150.36^{\mathrm{Cc}}$ & 43 & $46.19 \pm 2.982 \mathrm{ABab}$ & $36.38 \pm 0.769^{\mathrm{Cc}}$ \\
\hline & 44 & $340.61 \pm 9.053$ & 44 & $8500.87 \pm 246.52^{\mathrm{Bc}}$ & $7752.70 \pm 181.69^{\mathrm{BCc}}$ & 38 & $43.23 \pm 3.086^{\mathrm{ABab}}$ & $36.27 \pm 0.796^{\mathrm{Cc}}$ \\
\hline Overall & 556 & $325.19 \pm 2.21$ & 555 & $7184.9 \pm 67.8$ & $6745.0 \pm 54.6$ & 349 & $44.87 \pm 0.845$ & $30.44 \pm 0.314$ \\
\hline
\end{tabular}

LL: Lactation length, LMY: Lactation milk yield, 305-dMY: 305-d milk yield, PT: Peak time, PMY: Peak milk yield, RH: Red Holstein, SIM: Simmental, NS: Not significant, *: significant for $\mathrm{P}<0.05$, **: significant for $\mathrm{P}<0.01$, a,b,c: The difference between the groups with the same letter is insignificant for $\mathrm{P}<0.05, \mathrm{~A}, \mathrm{~B}, \mathrm{C}$ : The difference between the groups with the same letter is insignificant for $\mathrm{P}<0.01$.

\section{Milk Yield Traits}

Averages and standard errors of LL, LMY, 305-dMY, PT and PMY characteristics are given in Table 2. The overall means of LL, LMY, 305-dMY, PT and PMY were calculated as $325.19 \pm 2.21 \mathrm{~d}, 7184.9 \pm 67.8 \mathrm{~kg}, 6745.0 \pm 54.6$ $\mathrm{kg}, 44.87 \pm 0.845 \mathrm{~d}$ and $30.44 \pm 0.314 \mathrm{~kg}$, respectively.

Breed effect on LL was determined to be significant $(\mathrm{P}<0.05)$, however, calving season, calving year and parity effect were not significant $(\mathrm{P}>0.05)$. The means of LL were $333.00 \pm 5.405 \mathrm{~d}$ and $322.72 \pm 3.233 \mathrm{~d}$ in $\mathrm{RH}$ and SIM breeds, respectively. $\mathrm{RH}$ had an average LL of $10.28 \mathrm{~d}$ longer than the SIM breed $(\mathrm{P}<0.01)$. In this study, LL mean (322.72 $\pm 3.233 \mathrm{~d})$ calculated for the SIM breed was higher than the compiled results by Akbulut (1998), and studies of Çilek and Tekin (2006), Özkan and Güneş (2011b), Erdem et al. (2015) and Koç (2016b), compiling the studies on SIM breed. LL average reported by Koç (2009) for the MB breed raised in Aydın was lower than LL average for the SIM breed found in this study.

LL mean $(333.00 \pm 5.405 \mathrm{~d})$ calculated in this study for RH breed was lower than LL average reported by Yilmaz (2010) for the same breed raised in another enterprise in Aydin. LL average in this study for RH was longer than the LL average reported by Çerçi (2006) and Koç (2009) for $\mathrm{HF}$ and MB breeds.

The effects of breed $(\mathrm{P}<0.01)$, calving year $(\mathrm{P}<0.05)$ and parity $(\mathrm{P}<0.01)$ on LMY were found to be statistically significant, and calving season effect was not important (P>0.05). RH and SIM breed had LMY averages of $8235.32 \pm 148.099 \mathrm{~kg}$ and $7357.03 \pm 88.122 \mathrm{~kg}$, respectively. RH breed produced $878.29 \mathrm{~kg}$ more $(\mathrm{P}<0.01)$ milk than SIM breed, and LMY of cows giving birth in summer produced $253.09 \mathrm{~kg}$ less milk $(\mathrm{P}>0.05)$ than those of the winter calving cows.

The highest LMY was obtained in 2013 $(8312.15 \pm 244.40 \mathrm{~kg})$ and the lowest was in 2012 $(7525.75 \pm 226.11 \mathrm{~kg})$ where all animals were in the first lactation $(\mathrm{P}>0.05)$, the difference between these two years were statistically significant $(\mathrm{P}<0.05)$, and the other differences among the years were not significant $(\mathrm{P}>0.05)$.

Considering that the herd was newly established and animals were brought as pregnant heifers gave their first births in 2012, no animals would be in the first lactation in 2013. The heifers born in 2012 were used in breeding at 15-16 months of age and they gave birth at about 24 months of age and started producing milk in 2014. Since cows had lower milk yield levels in the first lactation and there were not any cows in the first lactation in 2013. Therefore, it can be said that the average of LMY in 2013 were higher than those of other years. In addition, LL mean of 2013 year was longer than the other years and as a result of that LMY of 2013 obtained higher than those of other years. 
As expected, LMY average increased regularly according to the parities, and the lowest LMY average was obtained as $6711.66 \pm 128.06 \mathrm{~kg}$ in the cows in the first lactation and reached the highest level in $5^{\text {th }}$ and higher lactations as $8500.87 \pm 246.52 \mathrm{~kg}$. The difference between the first parity and the $5^{\text {th }}+$ parity $(1789.21 \mathrm{~kg})$ was also found statistically significant $(\mathrm{P}<0.01)$. The $5^{\text {th }}+$ parity was different from the second parity $(\mathrm{P}<0.05)$, and the first parity was different from all other parities $(\mathrm{P}<0.01)$.

In this study, the mean LMY for RH breed $(8235.32 \pm 148.09 \mathrm{~kg})$ was lower than LMY average $(8484.49 \pm 109.28 \mathrm{~kg})$ previously reported by Y1lmaz (2010), who was working on the same breed. Çerçi (2006) for HF, Koç (2006) for HF and Brown-Swiss, and Koç (2009) for HF and MB breeds reported lower LMY averages than the mean found for RH in this study.

The mean LMY calculated for SIM breed $(7357.03 \pm 88.122 \mathrm{~kg})$ was higher than the means reported previously for the same breed by Akbulut (1998), Çilek and Tekin (2006), Özkan and Güneş (2011b), Erdem et al. (2015). In addition, the average LMY found for the SIM breed in this study was higher than the reported values for HF by Çerçi (2006) and HF and MB by Koç (2009).

The effects breed $(\mathrm{P}<0.01)$, calving season $(\mathrm{P}<0.05)$, calving year $(\mathrm{P}<0.05)$ and parity $(\mathrm{P}<0.01)$ on $305-\mathrm{gMY}$ were found to be statistically significant. In HF and SIM breeds, the means of 305-dMY were calculated as $7628.78 \pm 109.148 \mathrm{~kg}$ and $6938.09 \pm 64.945 \mathrm{~kg}$, respectively, and the difference of $690.69 \mathrm{~kg}$ between the breeds was statistically significant $(\mathrm{P}<0.01)$. The average of $305-\mathrm{dMY}$ for the cows that gave birth in winter $(7417.56 \pm 105.451$ $\mathrm{kg})$ was $268.26 \mathrm{~kg}(\mathrm{P}<0.05)$ higher than the cows that gave birth in summer $(7149.30 \pm 72.484 \mathrm{~kg})$. In this study, the mean of $305-d M Y(6938.09 \pm 64.945 \mathrm{~kg})$ calculated for the SIM breed was also higher than the means reported for same breed by Akbulut (1998), Şekerden (1999), Çilek and Tekin (2006), Özkan and Güneş (2011b), Erdem et al. (2015) and Koç (2016b) and higher than the averages of HF and MB breeds reported by Koç (2009).

The average of 305-dMY calculated in this study for RH breed $(7628.78 \pm 109.148 \mathrm{~kg})$ was higher than 305 dMY averages reported by Koç (2001) for HF, Çerçi (2006) for HF, and Koç (2009) for HF and MB breeds. The mean was quite close to the average $(7652.83 \pm 80.68 \mathrm{~kg})$ reported by Yilmaz (2010) for RH.

Similar to LMY, the lowest average of 305-gMY was obtained in $2012(6948.71 \pm 166.64 \mathrm{~kg})$ and the highest in $2013(7642.60 \pm 180.12 \mathrm{~kg})$. The years 2013 and 2014 were similar $(\mathrm{P}>0.05)$ to each other but these years were different from all other years $(\mathrm{P}<0.05)$. Other differences between the years were not significant $(\mathrm{P}>0.05)$.

According to parity, the mean of 305-dMY increased until the fourth parity $(7781.17 \pm 150.36 \mathrm{~kg})$, maintaining its high-level during 5 th + parity $(7752.70 \pm 181.69 \mathrm{~kg})$. The first parity $(6194.38 \pm 94.38 \mathrm{~kg})$ was different from all other parities $(\mathrm{P}<0.01)$ and the second parity $(7147.17 \pm 121.04$ $\mathrm{kg}$ ) was also different from the fourth and $5^{\mathrm{th}}+$ parities $(\mathrm{P}<0.05)$.

It can be said that the averages of 305-dMY of RH and SIM breeds in the farm are higher than those reported for HF and SIM breeds in previous studies. These high level of productivity of the breeds are due to the factors like good management and nutrition of the cows in the farms, and about $7000 \mathrm{~kg}$ of productivity reached in the SIM breed, which is known especially as a dual-purpose breed, shows that the milk yield level of the breed has been significantly improved. In addition to the advantages of fattening performance and disease resistance of SIM breed, in this study it was determined that the fertility, and also high level of milk yield of this breed show the reason why producers started turning towards this breed in recent years.

Except parity $(\mathrm{P}<0.01)$, not any other factors had statistically significant effect on PT. The time to reach PT of RH and SIM breeds is $46.55 \pm 2.196 \mathrm{~d}$ and $44.46 \pm 1.218$ $\mathrm{d}$, respectively. PT was the shortest at the third parity $(42.09 \pm 2.405 \mathrm{~d})$, and the longest was determined for the first parity (51.28 \pm 2.000$)$. The difference between these two parities was detected to be statistically significant $(\mathrm{P}<0.01)$, and other differences were not significant $(\mathrm{P}>0.05)$.

PT means obtained in this study for RH and SIM breeds (46.55 $\pm 2.196 \mathrm{~d}$ and $44.46 \pm 1.218 \mathrm{~d}$, respectively) were very close to a PT (46 ${ }^{\text {th }}$ day) reported by Koç $(2017 \mathrm{~b})$, who previously worked on RH breed.

The effects of breed $(\mathrm{P}<0.01)$, calving season $(\mathrm{P}<0.01)$, calving year $(\mathrm{P}<0.05)$ and parity $(\mathrm{P}<0.01)$ on $\mathrm{PMY}$ were important $(\mathrm{P}<0.05)$. PMY in RH and SIM breeds were $34.68 \pm 0.567 \mathrm{~kg}$ and $31.47 \pm 0.314 \mathrm{~kg}$, respectively. About $3.21 \mathrm{~kg}$ difference between the breeds was important $(\mathrm{P}<0.01)$. PMY was $1.89 \mathrm{~kg}$ higher in cows calving in winter $(34.02 \pm 0.541 \mathrm{~kg})$ than the cows that calved in summer $(32.13 \pm 0.365 \mathrm{~kg})(\mathrm{P}<0.01)$. PMY was the highest in $2013(34.60 \pm 0.902 \mathrm{~kg})$ and the lowest in 2015 $(31.95 \pm 0.557 \mathrm{~kg})$, the difference between these two years was statistically significant $(\mathrm{P}<0.05)$. PMY from the first parity to the fifth parity was $25.67 \pm 0.516 \mathrm{~kg}, 31.83 \pm 0.552$ $\mathrm{kg}, 35.21 \pm 0.620 \mathrm{~kg}, 36.38 \pm 0.769 \mathrm{~kg}$ and $36.27 \pm 0.769 \mathrm{~kg}$, respectively. The averages of the first and second parities PMY were different from each other $(\mathrm{P}<0.01)$ and also these parities were different from the other parities $(\mathrm{P}<0.01)$, other differences were not significant $(\mathrm{P}>0.05)$.

PMY $(34.68 \pm 0.567 \mathrm{~kg})$ determined for RH in this study was higher than a PMY value $(31.734 .68 \pm 0.567 \mathrm{~kg})$ reported by Koç (2017b) for RH, but the PMY for the SIM breed $(31.47 \pm 0.314 \mathrm{~kg})$ was very close to the value reported for the RH breed by Koç (2017b).

\section{Conclusion}

This study focused on fertility and milk yield characteristics of RH and SIM breeds that were preferred as alternative to HF in recent years. Milk yield of RH was higher than SIM breed, and also some significant difference was obtained between the breeds in terms of fertility traits such as DO, CI and GL. It was determined that the milk yield of Austria-origin SIM breed used in this study was around $7000 \mathrm{~kg}$. RH breed had a high milk yield level than SIM breed as expected. It is thought that the overall fertility performances of RH and SIM breeds determined in this study were better than HF compared to the previous studies in the region, and this is one of the reasons why these breeds are preferred by the producers in recent years.

The high performances achieved in terms of almost all traits in the enterprise where the SIM and $\mathrm{RH}$ breeds were 
reared in this farm showed that the environmental factors such as management-feeding-housing-herd management offered to the animals in the enterprise were also quite favorable. The higher performance of the breeds could be attributed to the permanent owner of the business as a veterinarian and also there was a veterinary health technician working full time in the enterprise. Findings from a study in which the SIM and RH breed were raised together with HF breed would be important in revealing the differences between HF and SIM breeds in terms of fertility and milk yield.

\section{References}

Akbulut Ö. 1998. A review for Simmental cattle performance in Turkey. Atatürk Univ. J. Agri. Fac., 29 (1): 43-49.

Çerçi S. 2006. Linear Evaluation of Holstein-Friesian Cows Raised in Some Cattle Farm in Aydın Province. Master Thesis. Adnan Menderes University, Graduate School of Natural and Applied Sciences. Department of Animal Science, Aydın/Turkey.

Çilek S, Tekin ME. 2005. Environmental factors affecting milk yield and fertility traits of Simmental cows raised at the Kazova State Farm and phenotypic correlations between these traits. Turk J Vet Anim Sci 29: 987-993

Çilek S, Tekin ME. 2006. Calculation of adjustment factors for standardizing lactations to mature age and 305-day and estimation of heritability and repeatability of standardized milk yield of Simmental cattle reared on Kazova State Farm. Turk. J. Vet. Anim. Sci. 30: 283-289.

Erdem H, Atasever S, Kul E. 2015 Relation of body condition score with milk yield and reproduction traits in Simmental cows. Large Anim. Rev. 21:231-234.

Koç A. 2013. Effect of somatic cell count and some environmental factors on milk yield and milk constituent of Red Holstein cows raised under Mediterranean climatic conditions. (Oral). VI ${ }^{\text {th }}$ International Conference: (Balkan Animal Science Conference) BALNIMALCON 2013.

Koç A. 2001. Genetic and Phenotypic Parameter Estimation of Holstein-Friesian Dairy Cattle Raised in Dalaman State Farms. Master Thesis. Adnan Menderes University, Graduate School of Natural and Applied Sciences. Department of Animal Science, Aydın/Turkey.

Koç A. 2006. Lactation milk yields and somatic cell counts of Holstein-Friesian and Brown-Swiss cattle reared in Aydin province. J. Anim. Prod., 47(2):1-8.
Koç A. 2009. A research on milk yield, milk constituents and reproductive performances of Holstein Friesian and Montbeliarde cows (Poster). XVIIth International Congress of FeMeSPRum, Mediterranean Federation of Health and Production of Ruminants" May 27-30, Perugia, Italy.

Koç A, Akçay H, Y1lmaz H. 2011. A research on the various traits of Red-Holstein. (Oral Presentation). 7th National Animal Science Conference, Çukurova University, Agricultural Faculty, Department of Animal Science, 14-16 September, 2011, Adana/Turkey.

Koç A. 2011. A study of the reproductive performance, milk yield, milk constituents, and somatic cell count of HolsteinFriesian and Montbeliarde cows. Turk. J. Vet. Anim. Sci. 2011; 35: 295-302.

Koç A. 2012. Short Communication. Effects of some environmental factors and extended calving interval on milk yield of Red Holstein cows. Spanish J. Agric. Res.. 10(3): 717-721.

Koç A. 2015. Effects of somatic cell count and various environmental factors on milk yield and foremilk constituents of Red-Holstein cows. Tarım Bil. Derg. 21 (3): 439-447.

Koç A. 2016a. A review on Simmental raising: 1. Simmental raising in the World and in Turkey. Adnan Menderes Univ. J. Agric. Fac.; 13(2): 97 - 102

Koç A. 2016b. A review on Simmental raising: 1. Studies in Turkey. Adnan Menderes Univ. J. Agric. Fac., 13(2): 103-112.

Koç A. 2017a. A Research on Herd Life of Holstein-Friesian, Red-Holstein and Simmental Cows. Adnan Menderes Univ. J. Agric. Fac., 14(2):63-68.

Koç A. 2017b. Effects of some environmental factors on milking time milk yield in Red Holstein cows. TURJAF, Food Science and Technology, 5 (8):917-922.

Özkan M, Güneş H. 2011a. Effects of some factors on reproductive characteristics of Simmental cattle on private farms in Kayseri. Istanbul Univ. J. Vet. Med. Fac., 37(1):35-41.

Özkan M, Güneş H. 2011b. Effects of some factors on milk yield characteristics of Simmental cows on commercial farms in Kayseri. Istanbul Univ. J. Vet. Med. Fac., 37(2):81-88.

SAS. 1999. Statistical analysis system for windows (Release 8.2). SAS Institute's Inc., Raleigh, NC, USA.

Şekerden Ö. 1999. Effects of calving season and lactation order on milk yield and milk components in Simmental cows. Turk. J. Vet. Anim. Sci., 23. Supp. 1:79-86.

Şekerden Ö, Doğrul F, Erdem H. 1999. Blood and milk protein polymorphism and their effects on various production traits in Simmental cows. Turk. J. Vet.Anim. Sci., 23. Supp. 1:87-93.

Y1lmaz H. 2010. A Research on Milk Yield and Milk Quality Characteristics of Red-Holstein Cows. Master Thesis. Adnan Menderes University, Graduate School of Natural and Applied Sciences. Department of Animal Science, Aydın/Turkey. 